\title{
Investigation of Locally Made Ceramic Filter for Household Water Treatment
}

\author{
Awaluddin Nurmiyanto' ${ }^{1}$ Agus Prasetya ${ }^{2}$ \\ 'Jurusan Teknik Lingkungan, Fakultas Teknik Sipil dan Perencanaan, Universitas Islam Indonesia \\ ${ }^{2}$ Jurusan Teknik Kimia, Fakultas Teknik, Universitas Gadjah Mada \\ e-mail: awaluddin@uii.ac.id
}

\begin{abstract}
This research have objective to develop and evaluate the performance of ceramic filter in using locally available material at Yogyakarta. Ceramic filter are made by pressing a mixture of clay, discarded pottery (grog) and combustible material (coconut fiber) into the molder. Curving processes are then applied to form tubular shape before firing it using kiln $\left(1005^{\circ} \mathrm{C}\right)$. Filtration test were performed gravitationally by flowing well water into ceramic filter. Filtered water quality was complying with Indonesia drinking water quality standard (E.Coli and turbidity) although it has low filtration rate $(0,461$ $\mathrm{L} / \mathrm{Hr}$ ). The most optimum ceramic filter in turbidity and bacterial removal was composition number 10 $\{$ clay + coconut fiber $4,5 \%(w / w)+$ grog $5 \%(w / w)\}$ that have average turbidity removal $88,2 \%$, and average E. Coli removal 100\%. $\mathrm{N}_{2}$ adsorption-desorption result on ceramic filter number 10 showed 0,04 $\mu$ more size, and $4,32 \mathrm{~m}^{2} / \mathrm{g}$ pore surface area. The result from the XRD (X-ray diffractometer) indicates crystal structure of calcite and quartz on ceramic filter surface. Energy Dispersive X-ray (EDX) analysis showed Carbon compound as the most material constituent within the filter. Whereas micro's photo using SEM (scanning electron microscopic) and TEM (transmitted electron microscopic) showed filter surface consists of stacked aggregates, separated by more randomly oriented particles.
\end{abstract}

Keywords: ceramic filter, coconut fiber, water treatment, material analysis.

\section{Introduction}

Even though Indonesia water resources accounted has for almost six percent of the world water resources or about 21 percent total water resources in the Asia Pacific region, in fact clean water is becoming serious problem in Indonesia. Based on data shows that water consumption tends to increase significantly, according to WEPA (1998) total water demand in 2000 is approximately 156,000 Million $\mathrm{m}^{3}$ per annum. It is predicted that the figure will be doubled to 356,575 million $\mathrm{m}^{3}$ per annum by 2015 . However the availability of clean water in term of quantity tends to decrease due to environmental degradation and pollution. The rate of water resources degradation accounted for $15-35 \%$ per capita annually. As well as Yogyakarta city, it's also face though challenges in terms of providing safe, clean drinking water for their citizen. The data show that from 131.84 houses in Yogyakarta, there is only 62.8 percent has domestic waste treatment. About 37.2 percent of household disposes their domestic waste directly to river body (BPS, 2008). Therefore, major rivers in Yogyakarta do not meet requirement for drinking water.

Household level water treatment or point-of-use (POU) technologies emerged as an effective and fast solution coping with the drinking water problem. Sobsey (2002) stated that POU technology 
has the potential to fill the service gap where piped water systems are not possible, potentially resulting in substantial positive health impacts in developing countries. Ceramic filter were recognized as one promising and accessible technologies for treating water at the household level (Clasen, and Caincross, 1991). Several studies have been conducted with various type of ceramic membranes forming material. In general, a ceramic filter can be described as a permeable selective barrier or a fine sieve. As reported by Sobsey et al (2008) ceramic filter made from porous fired clay, the ceramic membrane design consists of local clay, ground rice husk, and silver nitrate.

This research have objective to develop and evaluate the performance of ceramic filter in using locally available material at Yogyakarta including material analysis of ceramic filter, filtered water quaity and quantity. Main material were used in ceramic filter forming is clay. Coconut fiber and discarded pottery being selected as mixture component because those material fulfill the required characteristic which is also widely available in Yogyakarta. Moreover several home scale ceramic industry in Yogyakarta could strongly support implementation of this research.

\section{Method}

\section{Filter production process}

The filter production process begins with a grinding the clay and coconut fiber to create a fine powder. Consistency in the powder is obtained by sieving using sieving shaker machine. The two powders are then mixed with water in different composition (Table 1) to make slurry. After that the slurry kneaded into a molder (made from gypsum) for pressing to form clay log (Figure 1.a).
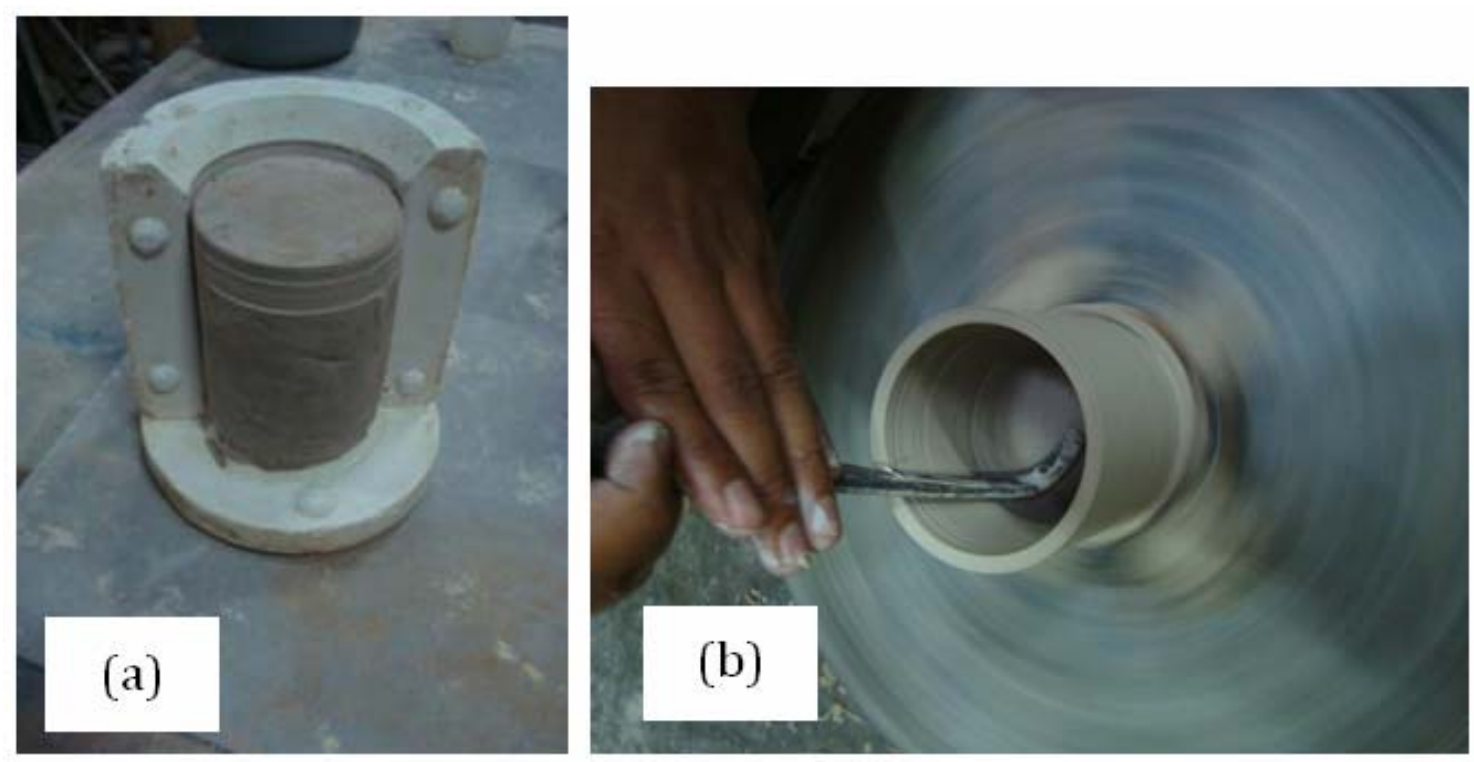

Figure 1. (a) Clay log inside the molder; (b) Filter shaping process. 


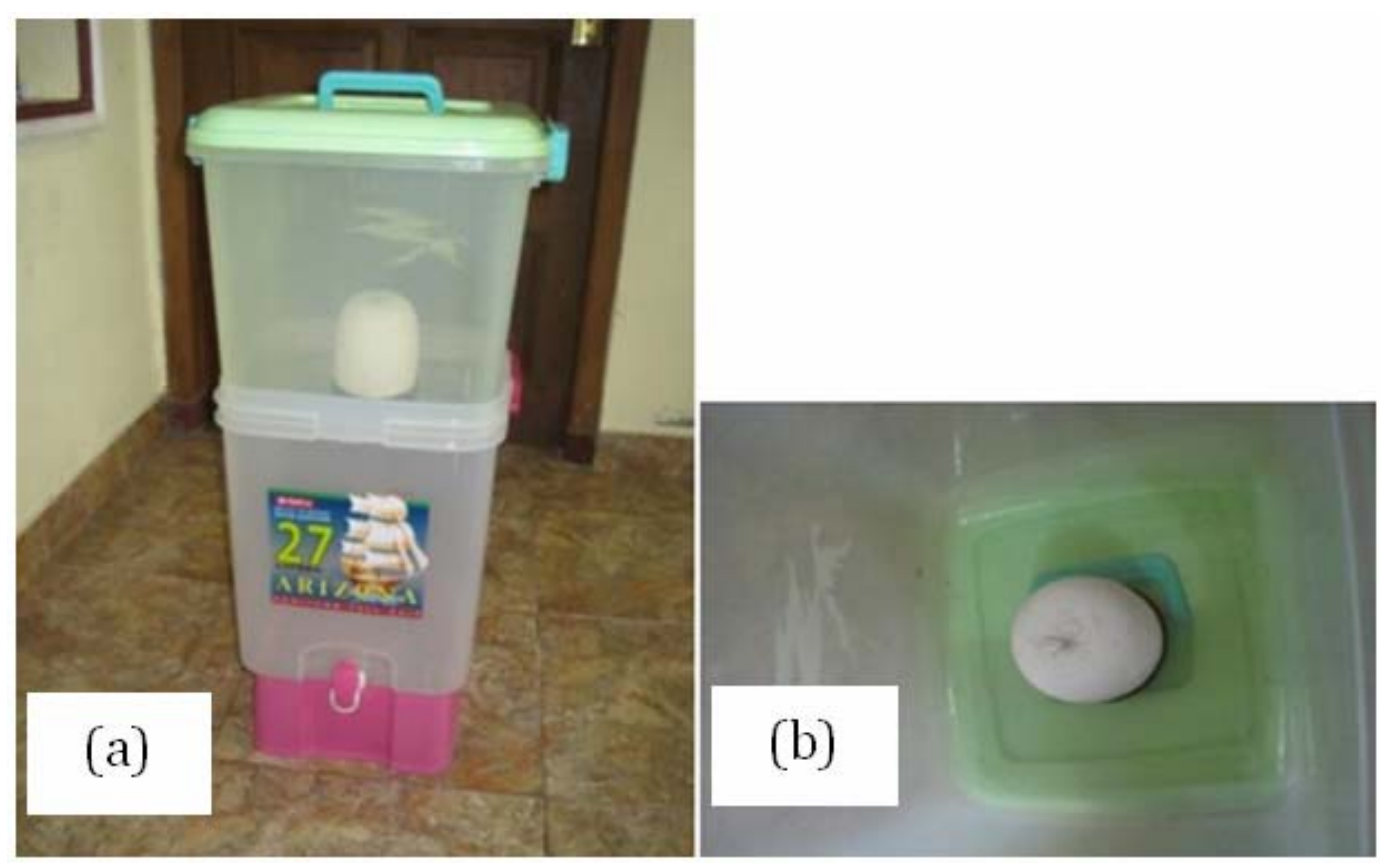

Figure 2 (a) Filtration test apparatus, (b) filter module.

To obtain the 'green' final shape of the filter, clay log are then placed on the rotating table and then curved by using knife (Figure 1.b). After dried it is fired in the kiln to burn out the sawdust and dewater. Because the limitation of the furnace, the firing process was done in two stage. $1^{\text {st }}$ stage conducted in $600^{\circ} \mathrm{C}$ temperature using gas furnace then continued to $2^{\text {nd }}$ stage in $1050{ }^{\mathrm{O}} \mathrm{C}$ temperature using electric furnace.

Table 1. Ceramic filter material constituent

\begin{tabular}{|l|l|l|l|l|}
\hline \multicolumn{1}{|c|}{ Material } & \multicolumn{1}{c|}{ Source } & \multicolumn{1}{c|}{ Function } & \multicolumn{1}{c|}{ Characteristic } & \multicolumn{1}{c|}{ Variation } \\
\hline Clay & $\begin{array}{l}\text { Singkawang } \\
\text { Clay* }\end{array}$ & Main material & $\begin{array}{l}\text { White color, mostly } \\
\text { kaolinite, sieved in } 60 \\
\text { mesh grain size. }\end{array}$ & $1500 \mathrm{gr}$ \\
\hline Coconut fiber & $\begin{array}{l}\text { Coconut fiber } \\
\text { waste (low grade } \\
\text { fiber) from } \\
\text { Rumah sabut } \\
\text { Yogyakarta }\end{array}$ & $\begin{array}{l}\text { Combustible } \\
\text { material }\end{array}$ & $\begin{array}{l}\text { Organic material, high } \\
\text { Carbon content, sieved } \\
\text { in } 120 \text { mesh grain size. }\end{array}$ & $\begin{array}{l}0 \% ; 1,5 \% ; \\
2,5 \% ; 3,5 \% ; \\
\text { qnd 4,5\% of } \\
\text { clay weight. }\end{array}$ \\
\hline Grog & $\begin{array}{l}\text { Pre fired clay } \\
\text { from discarded } \\
\text { pottery in } \\
\text { Kasongan, } \\
\text { Yogyakarta }\end{array}$ & $\begin{array}{l}\text { Filling material to } \\
\text { maintain }\end{array}$ & $\begin{array}{l}\text { Brown color, non } \\
\text { plastic material, sieved } \\
\text { in } 40 \text { mesh grain size. }\end{array}$ & $\begin{array}{l}0 \% \text { and 5\% of } \\
\text { clay weight. }\end{array}$ \\
\hline
\end{tabular}

note: *In Previous Study The Author Try To Use Local Clay From Kasongan (Yogyakarta) Unfortunately Kasongan's Clay Were Much Sandy And Contained Organic Matter Which Result In Lover Heat Resistance Compared Tisingkawang Clay. Heat Resistence Of Clay Could Be Very Helpful In This Research Because In Order To Get Small Pores Of Ceramic Filter, Clay Must Be Burned In High Temperature. 


\section{Filtration Test}

A laboratory scale test unit (Figure 2.a) was used to investigate ceramic filter performance. The unit includes ceramic filter module (Figure 2.b), equipped with two plastic buckets for water receptacle. Shallow well water in Code riverside area was used as water source in this test. During the filtration process the water passed through the filter by gravitational forces, filtered water thus to be collected and analyzed. Water quality sampling were conducted in every 1 hour; 2 hour; and 5 hour.

\section{Water Quality Test}

Filtered water samples were collected in sterile sample bottles and analyzed for total coliforms (TC), E. coli, and turbidity. Total Coliform and E.Coli bacteria determined by using Colilert ${ }^{\mathrm{TM}}$ reagent based on IDEXX ${ }^{\circledR}$ patented Defined Substrate Technology ${ }^{\circledR}\left(\mathrm{DST}^{\mathrm{TM}}\right)$. This product utilizes nutrient indicators that produce color and/or fluorescence when metabolized by total coliforms and E. coli. When the reagent is added to the sample and incubated, it can detect these bacteria in 24 hour. Confirmation test were conducted by placing a 6 watt $365 \mathrm{~nm}$ UV light within the sample in a dark environment and compared with the MPN table provided. While turbidity was measured two times each sample using a digital turbidity meter by HACH LANGE®.

\section{Material Analysis}

Ceramic filter were prepared for material characterization after filtration process to know the phenomena that may affect in filtration process. Several material analyses as displayed on Table 2.

Table 1. Summary of tools used in material analysis

\begin{tabular}{|c|c|c|c|}
\hline Type of Test & Method & Instrument & Function \\
\hline Surface imaging & $\begin{array}{l}\text { Scanning Electron Microscopy } \\
\text { (SEM); Transmission Electron } \\
\text { Microscopy (TEM) }\end{array}$ & $\begin{array}{l}\text { JEOL JSM-6360; } \\
\text { JEOL 2200FS }\end{array}$ & $\begin{array}{l}\text { Microstructure } \\
\text { analysis and surface } \\
\text { characterization of } \\
\text { ceramic filter }\end{array}$ \\
\hline $\begin{array}{l}\text { Material } \\
\text { composition }\end{array}$ & $\begin{array}{l}\text { Energy dispersive X-ray } \\
\text { spectroscopy (EDX) }\end{array}$ & JEOL JSM-6360 & $\begin{array}{l}\text { Material composition } \\
\text { within ceramic filter } \\
\text { surfaces }\end{array}$ \\
\hline Crystallization & $\begin{array}{l}\text { Energy Dipersive X-Ray } \\
\text { Spectroscopy (XRD) }\end{array}$ & Siemens D5000 XRD & $\begin{array}{l}\text { Identification of } \\
\text { crystal structure of } \\
\text { ceramic filter }\end{array}$ \\
\hline Pore analyses & $\begin{array}{l}\mathrm{N}_{2} \text { adsorption and desorption; } \\
\text { surface area using BET } \\
\text { formula; Pore size using and } \\
\text { pore distribution using BJH } \\
\text { formula }\end{array}$ & $\begin{array}{l}\text { ASAP2010 rapid } \\
\text { surface area \& pore } \\
\text { size tester } \\
\text { (Micromeritics Co., } \\
\text { USA) }\end{array}$ & $\begin{array}{l}\text { Determine the surface } \\
\text { area, pore size and } \\
\text { pore distribution on } \\
\text { ceramic filter surface }\end{array}$ \\
\hline
\end{tabular}




\section{Result and Discussion}

\section{Microstructure image}
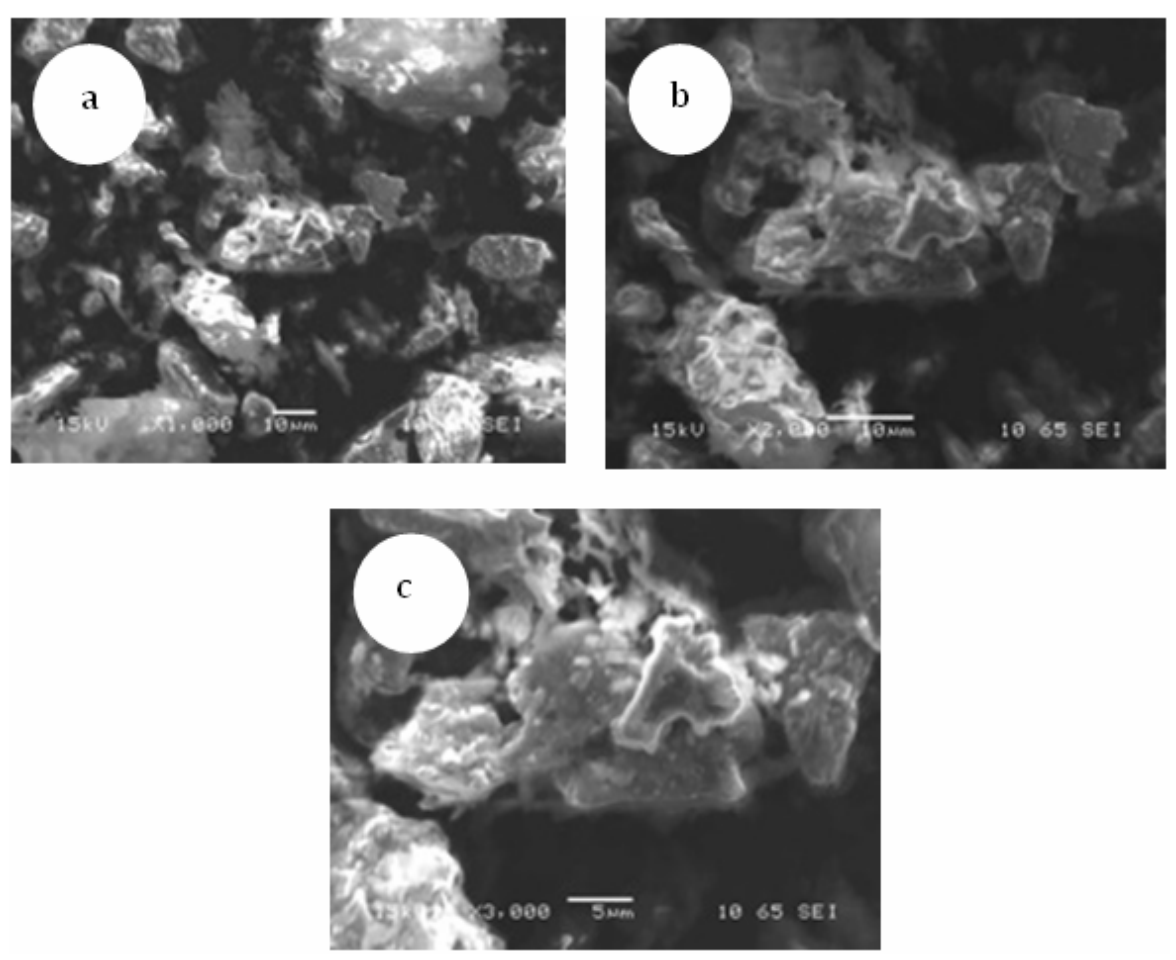

Figure 3. SEM image surface of investigated ceramic membrane filter, (a) 1000 times magnification; (b) 2000 times magnification; (c) 3000 times magnification.
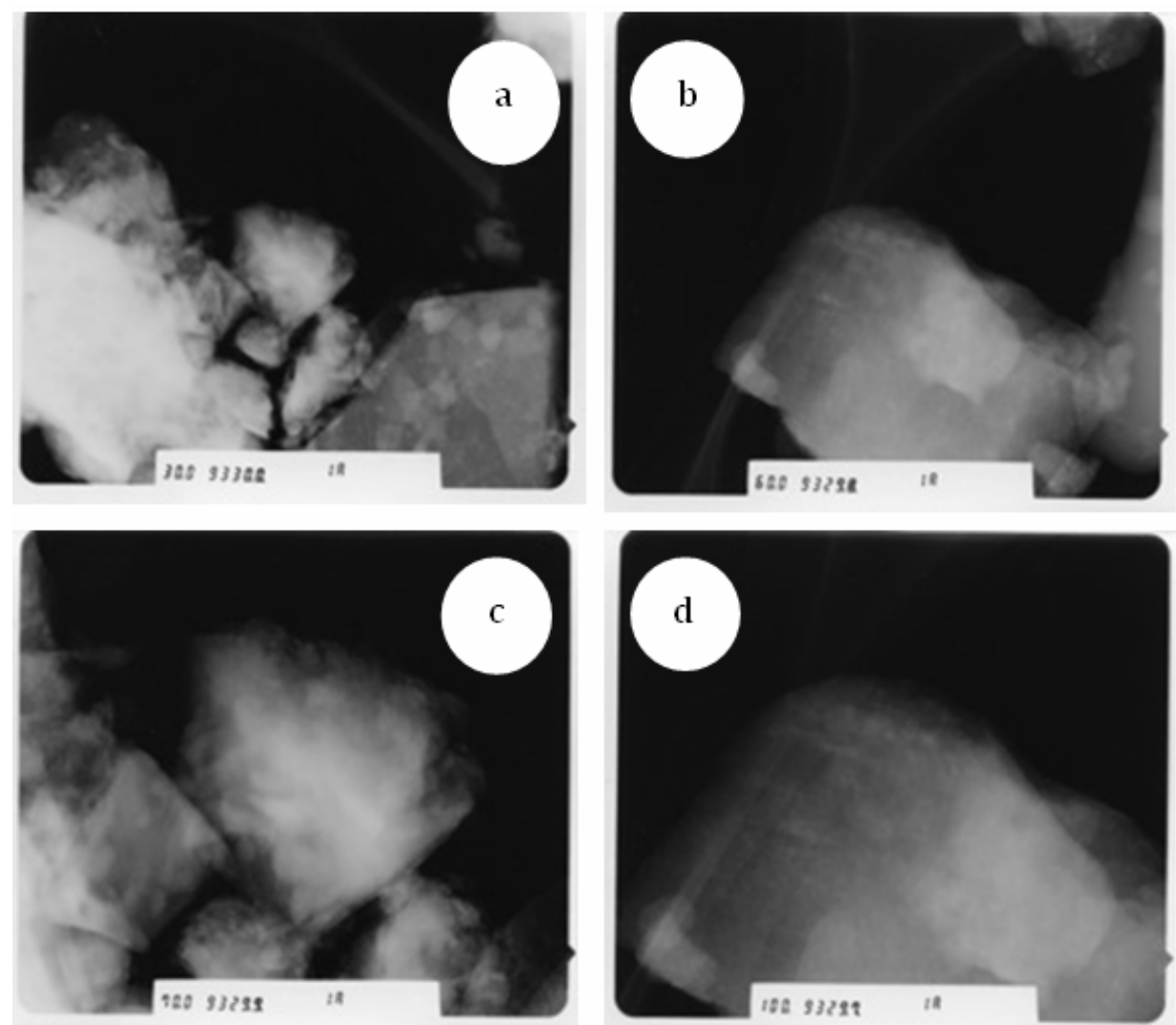

Figure 4. TEM image of investigated ceramic membrane filter, (a) 30x1000 times; (b) 60x1000 times; (c) 70x1000 times; (d) 100x1000 times magnification. 
Micro's photo using SEM (Figure 4) and TEM (Figure 5) showed membrane surface consists of stacked aggregates, separated by more randomly oriented particles. Pore area showed by the dark/black colors while the clay granules showed by the bright/white colors. Both SEM and TEM result indicate most of pore structure did not distributed evenly. It also can be seen if not all pore within the ceramic membrane were inter connected. There are some dead-end even isolated pores were founded. The dead-end pores and isolated pore within the ceramic membrane surface can be such problem on filtration rate. The isolated pores cannot contribute to the flux across the filter while 'Dead-end' pores are interconnected from one side only. Thus when the filter is filled with water all pores connected to the inside will fill with water but only interconnected pore can deliver the water as explained by Xiaolong (2005).

\section{Material Composition}

EDX result on ceramic membrane surface found some element including: Oxygen (O) 29,79\%; Magnesium (Mg) 3,83\%; Aluminum (Al) 7,64\%; Silica (Si) 19,98\%; Calcium (Ca) 3,39\%; and Carbon (C) 35,37\%. Comparing the EDX results with the clay composition theory, it shows similarity of some element like $\mathrm{Al}, \mathrm{Si}, \mathrm{K}, \mathrm{Mg}, \mathrm{Ca}$ and $\mathrm{O}$ all those element possible come from clay itself (Sulistarihani and Hermawan,1996). High carbon content in ceramic filter surface is strange result. Carbon content on ceramic membrane may yield from coconut fiber addition, but it should be less or even disappear when high temperature was applied on firing process. The possibility explanations about this phenomenon were: (1) the uneven temperature distribution in kiln. Uneven temperature distribution can make the heat cannot reach on every area in the kiln make some ceramic membrane did not fired completely thus it leave unburned carbon compound. (2) XRD test only conducted after filtration process thus the author presuming if high carbon content can be affected by the impurities that remain on ceramic membrane surfaces.

\section{Crystal structure}

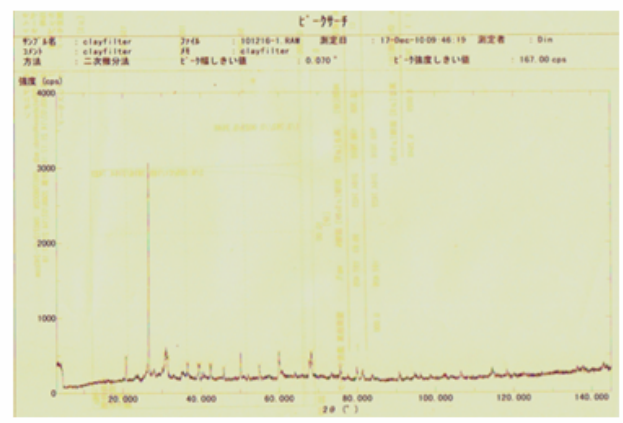

Tabel 3. Obtained peak in diffractogram

\begin{tabular}{|l|l|l|l|l|}
\hline No & $\boldsymbol{2 \theta}$ & Intesity & d space $(\boldsymbol{A})$ & Material \\
\hline 1 & 26,58 & 3071 & 3,35 & Quartz $\left(\mathrm{SiO}_{2}\right)$ \\
\hline 2 & 20,78 & 487 & 4,27 & Quartz $\left(\mathrm{SiO}_{2}\right)$ \\
\hline 3 & 42,3 & 320 & 2,13 & Calcite $\left(\mathrm{CaCO}_{3}\right)$ \\
\hline 4 & 45,68 & 279 & 1,98 & Aragonite $\left(\mathrm{CaCO}_{3}\right)$ \\
\hline 5 & 50,06 & 524 & 1,82 & Quartz $\left(\mathrm{SiO}_{2}\right)$ \\
\hline
\end{tabular}

Figure 5. Diffractogram of ceramic membrane 
The diffractogram from the XRD (X-ray diffractometer) in Figure 5 showed material crystallinity within the material, by plotting between $2 \theta$ (axis) versus intensity (ordinate). After some peaks were decided thus basal spacing (d) value were calculated using Bragg's Law as showed on Table 3. Obtained peak indicates if crystal structure of calcite and quartz were present on ceramic filter surfaces.

Higher temperature $\left(1050{ }^{\circ} \mathrm{C}\right)$ applied in firing process lead to crystal transformation, some crystal structure in Singkawang clay (mostly Kaolinic) may be broken and disappear. Previous research found that clay material transforming into oxide compounds and form crystalline compounds simultaneously depending on the heating time. Meda (2000) in Sustyaningsih et al (2008) heating up clay into $1000^{\circ} \mathrm{C}$ make Kaolin alleged and decomposed into amorphous alumina and amorphous silica. Wahyuni (1993) confirmed if Kaolinic crystal was destroyed at temperature higher than $600{ }^{\mathrm{O}} \mathrm{C}$.

\section{Pore diameter and sulfure area}

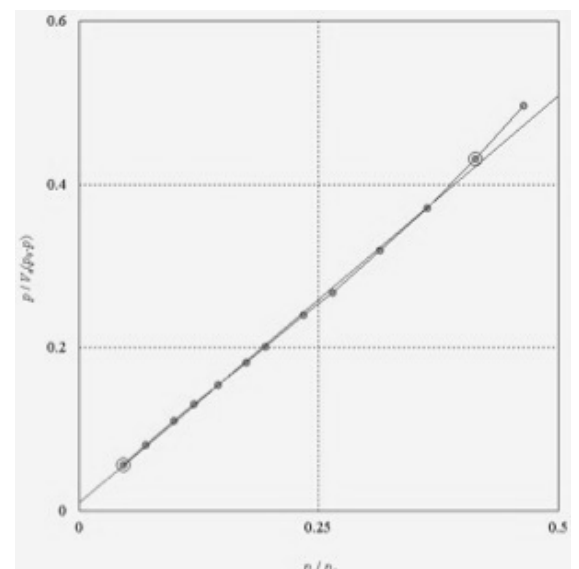

Figure 6. N2 adsorption and desorption isotherm plot of ceramic membrane

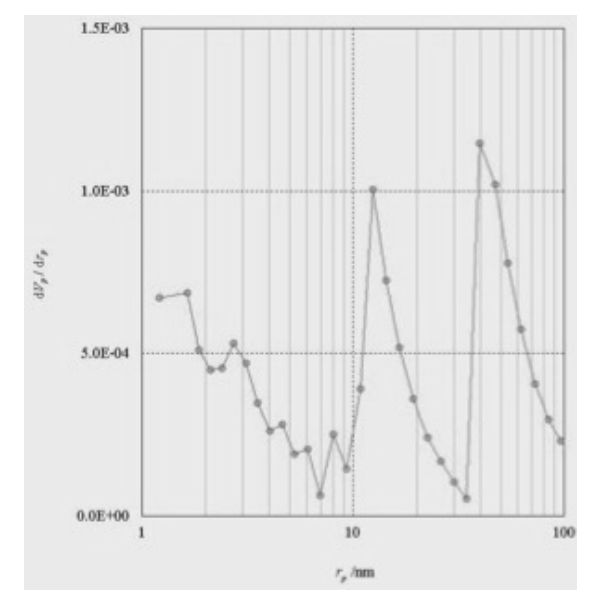

Figure 7. BJH pore distribution plot

The result of $\mathrm{N}_{2}$ absorption and desorption test for ceramic membrane in this research as displayed in isotherm curve (Figure 6). It can be seen from the graph that the isotherms relative flat and only small gaps between $\mathrm{N}_{2}$ adsorption desorption curve, namely the adsorption and desorption isotherms completely superposition, owing to the adsorption of the samples mostly occurs in the micro pores. Using BET formula, the specific surface area of ceramic membrane was $4,32 \mathrm{~m}^{2} / \mathrm{g}$ and average particle size was 44,064 $\mathrm{nm}$. While effective pore size diameters determined using BJH formula is $0,04 \mu \mathrm{m}$ and total pore area is $4,3249 \mathrm{~m}^{2} / \mathrm{g}$. Large surface area in ceramic membrane will lead to a better adsorption process compared to the narrow surface area. Obtained data from previous research were used to compare the surface area and also pore size as shown on Table 4. 
Table 2. Pore size and total pore area comparison of previous ceramic filter

\begin{tabular}{|l|l|l|}
\hline Country of origin & Pore size $(\boldsymbol{\mu} \mathbf{m})$ & Total pore area $\left(\mathbf{m}^{2} / \mathbf{g}\right)$ \\
\hline Cambodia* & $23 \mu \mathrm{m}$ & 0.67 \\
\hline Ghana * $_{\text {Nicaragua * }}^{*}$ & $19 \mu \mathrm{m}$ & 1.31 \\
\hline Made ceramic filter & $14 \mu \mathrm{m}$ & 1.22 \\
\hline
\end{tabular}

Made ceramic filter have larger surface area compared and smaller pore size compared to other. At least two phenomena can answer why such those differences happened, (1) smaller material grain sizes that used in this research as displayed on Table 1, (2) higher temperature applied in firing process. The other possibility may be affected by the difference of pore measurement method, Van Dalem et al (2009) using mercury intrusion method that considered more precise in measuring pore size compared to the BJH method.

\section{Filtration rate}

The filtration rate of ceramic filter (Figure 8 ) tend to increase by the time. The low filtration rate in the first one-hour can be explained by clogging phenomena, the test were made approximately three hours after pre treatment by submerging the filters in water. This short soaking time made the pores in ceramic filter were not fully open yet. Pre treatment like submerging the membrane in water for 24 hour (soaking) can help to clean the pore from the dust and burning material. Previous study said that filters should be soaked prior to filtration rate testing for reliable results (Lantagne, 2001). If filter soaked for fewer than 24 hours filters had lower filtration rates (Van Dalem, 2006).

The filtration rate changed after 5 hour, the filtration rates also become lower compared to the 2 nd hour. It may correlates with the fluid pressure on the bucket. Since the test already run for 5 hour it will decreasing the water level which resulted in lower pressure, therefore, the filtration rate will slow as the filter empties.

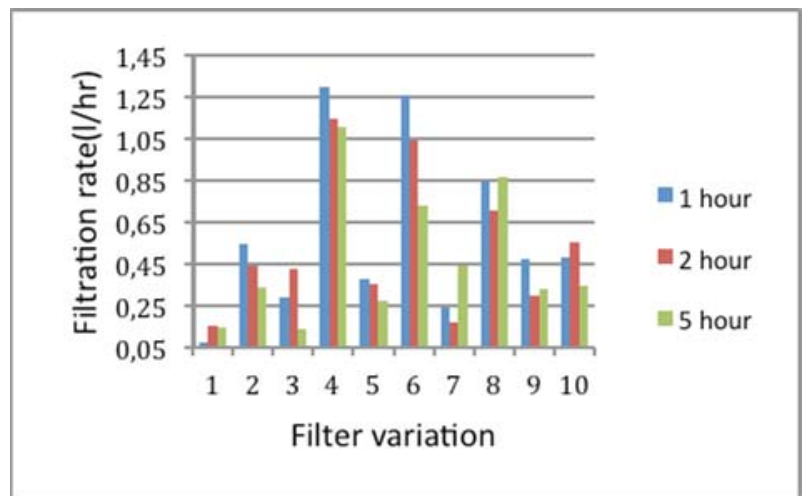

Figure 8. obtained ceramic membrane filtration rate

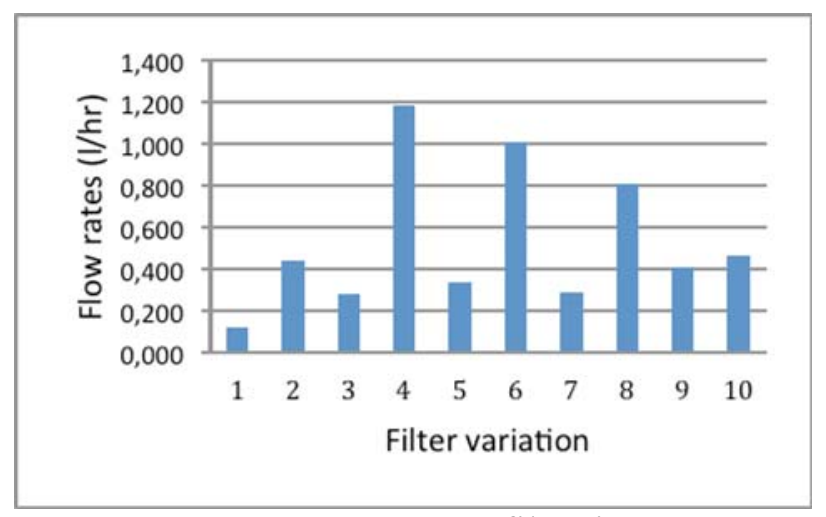

Figure 9. Average filtration 
Average filtration rates (Figure 9) ranged from $0.123 \mathrm{~L} /$ hour to $1.186 \mathrm{~L} /$ hour. The lowest filtration rate was obtained on filter variation no 1 (less combustible material) while the highest one obtained from membrane variation no 4 (contained more combustible material). Since on ceramic filter 4,6 and 8 has some cracking zone so obtained data cannot be used as comparison. Thus omitting that variation of filter, ceramic filter variation no 10 selected as the highest filtration rates $(0,461$ L/hour). The addition of combustible material not merely become one factor influence in controlling filtration rate since it showing inconsistent result, the surface area and pore distribution also take a place to make sure the water can filtration and spread uniformly through the ceramic filter. Pore distribution and surface area test showed that pore distribution were not evenly distributed thus it interfere with the filtration rate.

Addition of grog in ceramic composition also indicate the escalation of filtration rate, average filtration rate on membrane without addition grog (variation no $1-5$ ) tend to have lower filtration rate compared to membrane with addition of grog (variation no 6-10). Possible explanation is due to grog were made from fired clay, this material will not changed during firing process, thus leaving behind a slightly more porous ceramic filter.

\section{E.Coli removal}

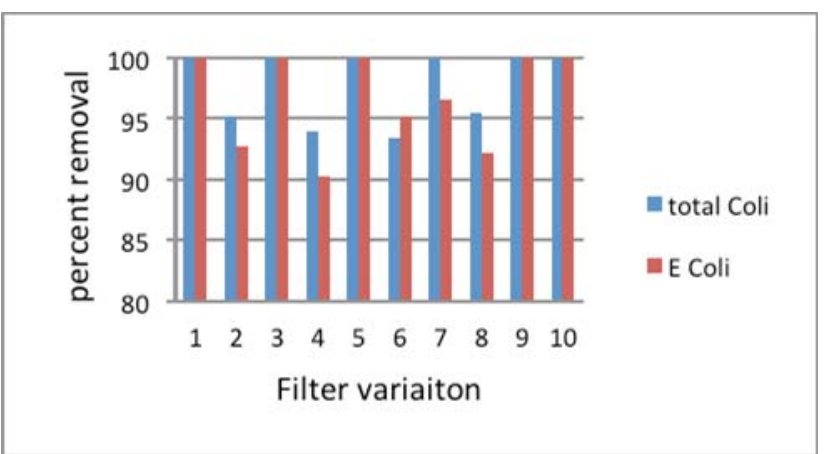

Figure 10. Percent of Coliform removed by ceramic membrane filter

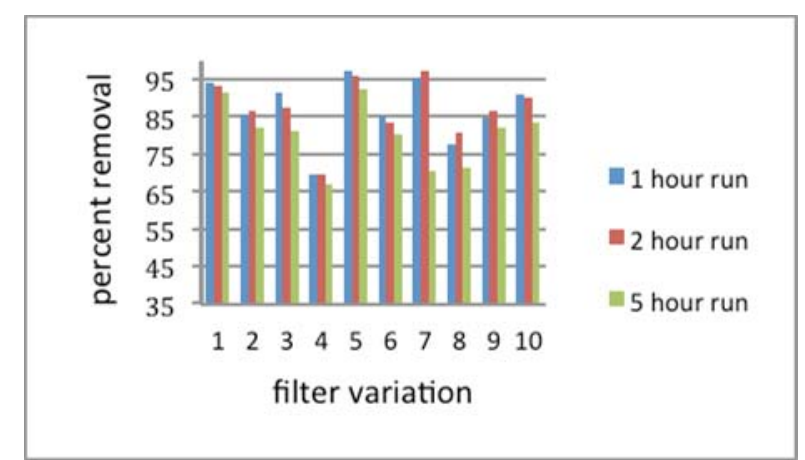

Figure 11. Percent turbidity removal by ceramic membranes

Ceramic filter can remove E. Coli above $90 \%$ in all variation (Figure.10), the highest E. Coli removal $(100 \%)$ belongs to ceramic filter variation number $1,3,5,9,10$, while the lowest E. Coli removal $(93,34 \%)$ belongs to ceramic filter variation number 4 . The addition of combustible material seems not to contribute on E. Coli removal efficiency because only slight differences in Coliform removal percentage between the ceramic filter variation. The obtained pore size data was $0,04 \mu \mathrm{m}$. While pathogenic bacteria have size around $0,2 \mu \mathrm{m}$ to $0.6 \mu \mathrm{m}$, thus smaller pore size can trap the E. Coli bacteria. 
The reduction of microbial pathogens through treatment by ceramic filtration may involve one or more physical or chemical processes. Mechanisms may vary widely between filters and have not been adequately characterized. So many variables were influence on E. Coli removal percentage, like the material and composition that used to produce ceramic membrane, the way to make ceramic membrane even the source water quality were different. In the case of low-cost locally made filters, Campbell (2005) said that the pore size varies widely by ceramic material, burnout material, firing temperature, and other factors; filter void spaces tend to have a tortuous configuration that may contribute to increased microbial removal efficiency.

\section{Turbidity removal}

Turbidity removal percentage of ceramic membrane as presented on Figure 11, it can be seen if the addition of combustible material tends to have lower turbidity removal percentage. Filter variation no 10 with higher combustible material (clay, grog 5\% and fiber 4.5\%) than variation no 5 (clay and fiber $4.5 \%$ ) slightly result in lower turbidity removal. Highest content of combustible make ceramic become more porous thus turbidity removal become less.

It was contradictive with the filtration rate results, lower turbidity removal tend to have higher filtration rate like membrane type no 10 (46.65\% turbidity removal and $0.217 \mathrm{~L} / \mathrm{s}$ in filtration rate). Addition of combustible material will make the pore bigger thus it increase the filtration rate but lowering the turbidity removal percentage. The optimum performance of ceramic membrane is which has good removal but also has high filtration rate.

Reliability of locally made ceramic membranes as Point of Use Technology (POU) in water treatment.

After some ceramic membrane data (both of material and removal performances) were obtained, all those data were used to indicate that it is, or is not, appropriate or reliable as POU water treatment. The reliability of ceramic filter were assessed based on quality and quantity.

Table 3. Water quality comparison

\begin{tabular}{|l|l|l|l|l|}
\hline No & Selected parameter & \multicolumn{1}{c|}{ standard } & \multicolumn{1}{c|}{ Filter effluent } & \multicolumn{1}{c|}{ Note } \\
\hline 1 & Turbidity & $5 \mathrm{NTU}$ & $0,731 \mathrm{NTU}$ & Acceptable \\
\hline 2 & E. Coli & $0 \mathrm{MPN} / 100 \mathrm{ml}$ & 0 & Acceptable \\
\hline 3 & Total Coliform & $0 \mathrm{MPN} / 100 \mathrm{ml}$ & 0 & Acceptable \\
\hline
\end{tabular}


Filtered water quality (Table 5) were compared with Indonesian drinking water quality standard (PERMENKES No.492/Menkes/Per/IV/2010). Result on this study has been proved that ceramic membrane filter has good ability in water quality enhancement, all selected parameter were comply with the Indonesian drinking water quality standard. Further research it should be tested for other drinking water parameter such as viruses, other pathogenic microbe and metal content in the water to ensure the ability of ceramic membrane filter.

Quantity assessment also conducted on filtered water by comparing with based water consumption (Table 6). Based on the best performance of ceramic filter (variation no 10) it has average filtration rate about $0,461 \mathrm{~L} / \mathrm{hr}$. Suppose to fulfill daily water consumption about $50 \mathrm{~L} /$ cap/day (single tap) it require 108 hour (4,5 day) to operate the ceramic membrane filter, that was long time and not feasible in water quantity. But $50 \mathrm{~L} / \mathrm{cap} /$ day is for all domestic consumption including drink, cook, bath and wash. For drinking water requirement, some health authorities have suggested at least eight glasses each $(240 \mathrm{~mL})$ of water per day or $1.89 \mathrm{~L} /$ day, thus to fulfill minimal drinking water consumption/person/day the ceramic membrane filter must be operated around 4 hour. For instance one house has four persons thus drinking water requirement is about 7,56 L/day and need to operate the ceramic membrane filter for 16,3 hour. Based on drinking water requirement these products already meet the minimum requirement, but for overall domestic requirement further improvement in water filtration rate should be developed.

Table 4. Water quantity comparison

\begin{tabular}{|l|l|l|}
\hline \multicolumn{1}{|c|}{ Types of water supply } & \multicolumn{1}{c|}{ Typical consumption (L/Cap/day) } & \multicolumn{1}{c|}{ Range (L/Cap/day) } \\
\hline Communal standpipe & 30 & $20-50$ \\
\hline Yard connection & 40 & $20-80$ \\
\hline House conncetion & & \\
\hline$\bullet \quad$ Single tap & 50 & $30-60$ \\
\hline$\bullet \quad$ Multiple tap & 150 & $70-250$ \\
\hline
\end{tabular}

\section{Conclusions and Recommendations}

After all the research activities undertaken in this thesis it can be drawn a conclusion as follows:

1. The most optimum performance was ceramic membrane filter variation 10 (clay+combustible material $4,5 \%(w / w)+\operatorname{grog} 5 \%(w / w))$;

2. Material analysis on ceramic filter showed: (a) The effective pore size diameters measured using $\mathrm{N}_{2}$ adsorption-desorption apparatus was $0,04 \mu \mathrm{m}$ while total pore area was $4,3249 \mathrm{~m}^{2} / \mathrm{g}$; (b) The result from the XRD (X-ray diffractometer) indicates crystal structure of calcite and quartz; (c) Micro's photo using SEM (scanning electron microscopic) and TEM (transmitted electron microscopic) showed filter surface consists of stacked aggregates, separated by more 
randomly oriented particles; (d) EDX result on ceramic filter surface found some element including: Oxygen (O); Magnesium (Mg); Aluminum (Al); Silica (Si); Calcium (Ca); and Carbon (C).

3. Produced ceramic membrane filter has good ability in water quality enhancement, since selected parameters (E.Coli, TC, and Turbidity) were complying with the Indonesian drinking water quality standard. Although has low flow rate $0,461 \mathrm{~L} / \mathrm{hr}$, which is insufficient to provide drinking water for a family.

For complete and comprehensive result, the author recommended some point that should be considered in the next research as follows:

1. Manual molding technique of ceramic membrane filter production cannot easily maintain the quality (pore distribution) of produced membrane;

2. Considered to test efficiency of ceramic membrane filter on other water quality parameter such as metal and virus on longer period.

\section{Acknowledgments}

The tuition of this research was supported by Beasiswa Unggulan, Biro Kerjasama Luar Negeri (BPKLN), Directorate of Higher Education (DIKTI), Indonesian Ministry of Education.

\section{References}

Clasen, T. F., Caincross, S. (2004). Household Water Management: Redefining the Dominant Paradigm. Tropical Medicine and International Health Journal, Vol.9 No. 2.

Badan Pusat Statistik, BPS. (2009). Yogyakarta Dalam Angka 2008.

Dies, R.W. (2003). Development Of A Ceramic Water Filter For Nepal. Master of Engineering Thesis on Department of Civil and Environmental Engineering, Massachusetts Institute Of Technology. MA. http://web.mit.edu/watsan/Docs/Student\%20Theses/Nepal/Dies2003.pdf $(03 / 10 / 11)$.

IRC. (1981). Small community water supplies, International Reference Center for Community Water Supply and Sanitation, The Hague, Netherlands. http://greenplanet.eolss.net/EolssLogn/mss/C07/E2-14/E2-14-03/E2-14-03-01/E2-14-03 01T02.htm (7/10/2011).

Lantagne, D.S. (2001). Investigation of the Potters for Peace Colloidal Silver Impregnated Ceramic Filte. Alethia Environmental Report. Allston, MA,USA. http://pottersforpeace.org/wpcontent/uploads/alethia-report-2.pdf (24/10/11). 
Sobsey, M. (2002). Managing water in the home: accelerated health gains from improved water supply. Geneva: World Health Organization. WHO/SDE/WSH/02.07.

Mark D, Sobsey. Christine, Stauber, Lisam. Cassanova, Joseph Brown. (2008). Point of use household drinking Water filtration: a practical, Effective solution for providing Sustained access to safe drinking Water in the developing world. Environmental Science and Technolgy Journal. Vol.42 No.12. 4261-4267.

Sulistarihani, Naniek and Hermawan. (1996). Reduksi Karbotermal Lempung Manado dan Belitung Menggunakan Karbon dalam Aliran Gas Argon, Indonesian Journal of ceramic and glass. Vol.5 No.1.

Sustyaningsih. R., Kismolo. E., Basuki. K.T. (2008). Pengaruh Penambahan MgO Pada Peningkatan Kualitas Lempung Kasongan Untuk Immobilisasi Lumpur Limbah $\mathrm{Pb}$ Menggunakan Teknologi Keramik, Proceeding on Seminar Nasional V SDM Teknologi Nuklir,Yogyakarta.25-28 Augustus 2008. 331-338.

Van Dalem. (2006). Ceramic Silver Impregnated Pot Filters For Household Drinking Water Treatment In Developing Countries. Master of Science Thesis on Civil Engineering. Sanitary Engineering Section. Department of Water Management. Faculty of Civil Engineering. Delft University of Technology. Nederland.

Van Dalem, Van der Laan, H., Heijman, S.G.J., van Dijk, J.C. and Amy, G.L. (2009). Assessing the sustainability of the silver-impregnated ceramic pot filter for low-cost household drinking water treatment. Physics and Chemistry of the Earth Journal. Vol.34 No. 2. 36-42.

Wahyuni. E.T. (1993). Penggunaan Metode Difraksi Sinar-X Untuk Deteksi Perubahan Kristal Mineral Lempung Akibat Pemanasan dan Aktivasi. Berkala Ilmiah FMIPA-UGM, Vol. IV No. 3.

Water Environment Partnership in Asia, WEPA. (1998). Indonesian state of water http://www.wepa-db.net/policies/state/indonesia/indonesia.htm (9/01/2010).

Xiaolong, L., and M.S.C. Yi. (2005). The method to define the pore diameter and its distribution for porous membrane. Tianjin Montian Company, Tianjin Plytechnic University, Tianjin. 